Ayurlog: National Journal of Research in Ayurved Science http://www.ayurlog.com Volume: $6^{\text {th }} \mid$ Issue: $5^{\text {th }} \mid$ August 2018

\title{
A clinical study of Phalatrikadi Ghrita Tarpana In The Management of Myopia
}

\section{Rajendra Singh Patel ${ }^{* 1}$, Yogesh Kumar Sisodiya ${ }^{2}$, Tushar Firke ${ }^{3}$}

1. PG Scholar,

2. PG Scholar,

3. Professor \& HOD

\section{Dept. of Shalakya Tantra}

\section{S. M. B. T. Ayurved College \& Hospital, Dhamangaon, Nashik (Maharashtra)}

*Corresponding author: dr.rajendrasinghpatel17@gmail.com

\begin{abstract}
:
In Ayurveda, clinical features related to visua disturbances are generally seen in Drishtigat Rogas. Hence, all the cases of visual disturbances can be correlated under the broad umbrella of Timira-Kacha-Linganasha complex. The part of clinical features of Timira (1st and 2nd Patalagata) can be correlated to myopia, there is a complaint of difficulty in seeing objects distinctly along with headache, eye strain, photophobia and lacrimation. The prevalence of myopia in Asia is high as 70$90 \%$. The Ayurvedic science can be explored to find a better alternative to manage this condition. In Ayurveda there is the concept of Akshi-Tarpana is the foremost procedure for Timira which provides Vatashamaka effect to he eyes along with providing nourishment. Io I has been select Akshi-tarpana with phalatrikadi ghrita along with poorvakarma and shamana chikitsa. This study had been carried out on 10 patients for a period of 46 days, in which Poorva karma Kostha shodhana and Nasya for 6 days, Pradhankarma Akshitarpana for 5 days into 3 sitting regular interval of 5 days, Shamana chikitsa Saptamrita lauha $250 \mathrm{mg}$ BD with madhu and ghrita. This treatmemt gives nourishment and strength to eye muscles so there was found markedly improvement in symptoms of myopia.
\end{abstract} Chaksushya (beneficial for vision) drugs and food items. Local therapeutic procedures for eye have been grouped under the umbrella of Kriyakalpa by our Acharyas and among them,

Keywords: Timira, Myopia, Akshitarpana 
INTRODUCTION:- In Ayurveda, clinical features related to visual disturbances are generally seen in Drishtigata Rogas. Hence, all the cases of visual disturbances can be correlated under the broad umbrella of Timira-KachaLinganasha complex. The part of clinical features of Timira (1st and 2nd Patalagata) can be correlated to myopia. When the vitiated doshas are located in the 1 st $\& 2^{\text {nd }}$ patala, there is a complaint of difficulty in seeing objects distinctly. This is a common complaint of all the refractive errors.

When the vitiated doshas are situated in the 2nd Patala, the patient complaints of confused visual perceptions and appearance of bees, flies, hairs etc. in fror of eyes. These symptoms are also seen in high myopia, where degenerative changes are common. Myopia or nearsightedness manifests as distant blur. The prevalence of myopia in Asia is as high as $70-90 \%$. Recent data suggests that a large number of people are blind in different parts of the world due to high refractive errors. The prevalence of blindness in India due to refractive error has been reported to be as high as $0.21 \%$ for all age groups in the population and another $0.03 \%$ of this population was irreversibly blind due to myopic retinal degeneration. Methods of correction of myopia are not without complications including corneal infections due to contact lens wear and corneal scarring and persistent corneal haze from refractive surgery.

Hence, the Ayurvedic science can be explored to find a better alternative to manage this condition. In Ayurveda there is the concept of Chaksushya (beneficial for vision) drugs and food items. Also some life style changes and some therapeutic procedures have been mentioned which improve or enhance the visual acuity as well as improve the overall health of the eye.

Conduction of light needs some medium to travel and same is for Vata also. Vata functions in the fluid media and Kapha is he predominant dosha in the fluid. So,we can say that Vata functions in Kapha media, refraction is a combined action of Vata and Kapha.

Snehana has been mentioned as supreme treatment for Vata Dosha by Charaka and he was mentioned Akshi-Tarpana as one of the 24 Snehapravicharna. Local therapeutic procedures for eye have been grouped under the umbrella of Kriyakalpas by our Aacharyas and among them, Akshi - Tarpana is the foremost procedure for Timira which provides Vatashamaka effect in the eyes along with providing nourishment. So I has been selected Aksitarpana with phalatrikadi ghrita, 
which is effective and easily available drug.

\section{METHODOLOGY :-}

According to Ayurveda selection of drug is based on many suitable factor that are involved in pathogenesis of particular disease, as the treatment is nothing but only samprapti vightana. In this case treatment mainly aimed to treat myopia (pratham and dwitiya patalgata timira) with alochaka pitta anurakshana. Thus following drugs were selected for present condition.

\section{STUDY PLAN:-}

Total 10 patients suffering form Myopi were selected by clinical examination OPD \& IPD department of shalakyatantra.

Examinations- Patients were examined by

- Snellen's chart for visual acuity.

- Retinoscopy examination.

- Ophthalmoscopic examination.

\section{TREATMENT PROTOCOL:-}

In Ayurvedic samhitas many types of treatment described for Timira chikitsa but I had selected following treatment for Timira (Myopia). The treatment was carried out for 46 days. During this period, Patient was advised for laghu, supachya aahara.
1) POORVA KARMA- For the poorvakarma of the procedure, following drugs were used in all patients-

Haritaki churna- 05 gm HS with luke warm water for 3 days.

Nasya karma- Anu taila nasya 4-5 drops each nostril for next 3 days.

\section{2) PRADHANA KARMA-}

Tarpana with phalatrikadi ghrita for 5 days into 3 sitting regular interval of 5 days.

\section{3) SHAMANA CHIKITSA -}

Saptamrita lauha 250mg BD with madhu and ghrita for 40 days start along with tarpan therapy.

\section{Phalatrikadi Ghrita:-}

"Phalatrikabhiru Kashayasiddham, Kalken Yashtimadhukasya Yuktam /

Sarpi Samam Chhodra Chaturthbhagam, Hanyat Tridosham Timiram Pravriddham //

(Chakradutta Netra Roga 59/188)

Phalatrikadi ghrita have Rasayana, Chakshushya and Balya properties. All Aacharyas mentioned these ingredients as Chakshushya and very effective in treating the eye disorders.

Inclusion criteria:- 
- Age Group-15 years to 30 years.

- Patients having symptoms of Myopia were selected.

- No discrimination of sex and economic status.

- Patients having spherical refractive error.

- Patients having refractive error up to $-2 \mathrm{D}$.

\section{Exclusion criteria:-}

- Age Group: - >15 years and <30 years.

- Patients having major ocular diseases like corneal ulcer, malignant condition of retinoblastoma, ocular tumor, D.M., leprosy, HIV, Tuberculosis.

- Patients with pathological myopia.

- Patients using other systemic drugs.

- Patients after surgeries like LASIK, Photo refractive keratectomy, Radial keratectomy etc.

\section{ASSESMENT CRITERIA -}

Assessment was done on the bases of clinical signs and symtoms in patients. For this purpose main clinical signs and symptoms were given with suitable scores according to their severity before, during and after treatment.

\begin{tabular}{|c|c|}
\hline $\begin{array}{l}\text { Avyakta darshana } \\
\text { (Blurred vision ) }\end{array}$ & $\begin{array}{l}\text { 0-No feeling of blurred vision. } \\
\text { 1-Occasional blurred vision. } \\
\text { 2-Regular blurred vision without disturbing routine work. } \\
\text { 3-Regular blurred vision disturbing day to day work. }\end{array}$ \\
\hline Headache & $\begin{array}{l}\text { 0-No headache. } \\
\text { 1-Occasional headache. } \\
\text { 2-Irregular attacks of frequent headache. } \\
\text { 3-Regular Headache. }\end{array}$ \\
\hline Eye strain & $\begin{array}{l}\text { 0-No eye strain. } \\
\text { 1-After } 4 \text { to } 6 \text { hours of near work. } \\
\text { 2-After } 2 \text { to } 4 \text { hours of near work. } \\
\text { 3-Before } 2 \text { hours of near work. }\end{array}$ \\
\hline Lacrimation & $\begin{array}{l}\text { 0-No lacrimation. } \\
\text { 1-Mild lacrimation. } \\
\text { 2-Moderate lacrimation. } \\
\text { 3-Severe lacrimation. }\end{array}$ \\
\hline Photophobia & $\begin{array}{l}\text { 0-No difficulty in seeing in sunlight. } \\
\text { 1-Occasional difficulty seeing in sunlight. } \\
\text { 2-Regular difficulty without disturbing routine work. } \\
\text { 3-Regular difficulty disturbing day to day work }\end{array}$ \\
\hline
\end{tabular}


- Follow up after the treatment, all after 15 days.

patients were advised to attend the OPD

\section{RESULT:}

Effect OF Phalatrikadi Ghrita Akshi-Tarpana on associated complaints of Myopia

\begin{tabular}{|l|l|l|l|l|l|l|}
\hline \multirow{2}{*}{$\begin{array}{l}\text { Sr. } \\
\text { No. }\end{array}$} & Parameters & \multicolumn{2}{|c|}{ Mean \pm SD } & \% relief & "t" Value & "p" Value \\
\cline { 3 - 5 } & & $\begin{array}{l}\text { Before } \\
\text { treatment }\end{array}$ & $\begin{array}{l}\text { After } \\
\text { treatment }\end{array}$ & & \\
\hline 1. & Blurred vision & & & 62.5 & 9 & $<0.0001$ \\
\hline 2. & Headache & $1.600 \pm 0.5163$ & $0.400 \pm 0.5163$ & 75 & 9 & $<0.0001$ \\
\hline 3. & Eye strain & $1.600 \pm 0.5163$ & $0.600 \pm 0.5163$ & 62.5 & 4.743 & 0.0011 \\
\hline 4. & Lacrimation & $1.300 \pm 0.4830$ & $0.400 \pm 0.5163$ & 69.23 & 5.014 & 0.0007 \\
\hline 5. & Photophobia & $1.600 \pm 0.5163$ & $0.500 \pm 0.527$ & 68.75 & 11 & $<0.0001$ \\
\hline
\end{tabular}

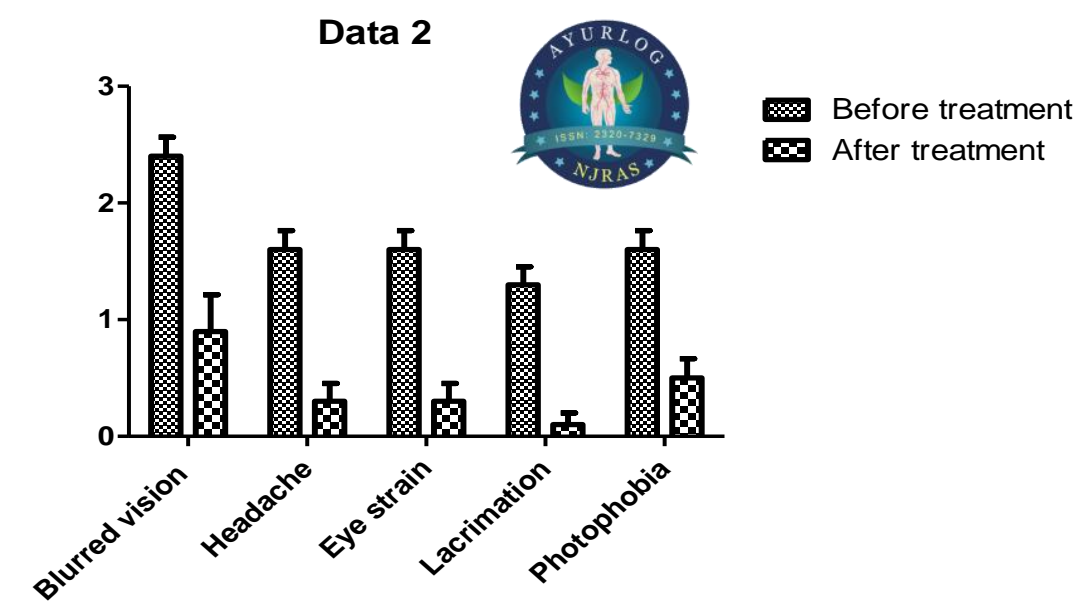

Effect OF Phalatrikadi Ghrita Akshi-Tarpana on Clinical Refraction (myopic spherical)

\begin{tabular}{|c|c|c|c|c|c|c|}
\hline \multirow[t]{2}{*}{ EYE } & \multirow{2}{*}{$\begin{array}{l}\text { No. of } \\
\text { Patients }\end{array}$} & \multicolumn{2}{|c|}{ Mean \pm SD } & \multirow[t]{2}{*}{$\%$ Relief } & \multirow[t]{2}{*}{ "t" Value } & \multirow[t]{2}{*}{ "p" value } \\
\hline & & $\begin{array}{l}\text { Before } \\
\text { treatment }\end{array}$ & $\begin{array}{l}\text { After } \\
\text { treatment }\end{array}$ & & & \\
\hline $\mathrm{RE}$ & 10 & $1.450 \pm 0.422$ & $1.225 \pm 0.343$ & $15.5 \%$ & 1.308 & 0.002 \\
\hline LE & 10 & $1.275 \pm 0.463$ & $1.00 \pm 0.486$ & $21.6 \%$ & 1.296 & 0.002 \\
\hline
\end{tabular}


The scoring of criteria of assessment was analyzed statistically in term mean value of before treatment (B.T.), after treatment (A.T.), standard deviation. Various observation made and result obtained were computed statistically using on graphpad instat software. Result of 10 patients shorted that symptomatic improvement was considerable in all parameters of Myopia.

It has been observed that symptom like Blurred vision shows changes from mean value 2.4 to 0.9 showing a reduction of 1.5 (62.50\% relief ), Headache shows changes in mean value from 1.60 to 0.4 showing a reduction of 1.2 (75\% relief), eye strain shows changes in mean value from 1.60 0.60 showing a reduction of $1.0(62.5 \%)$, lacrimation shows changes in mean value from 1.30 to 0.40 showing a reduction of 0.9 (69.23\%), photophobia shows changes in mean value from 1.6 to 0.5 showing a reduction of 1.1 (68.7\% relief), which are all statistically significant.

\section{DISCUSSION:}

- Any research without being discussed about its utility and importance is said to be incomplete, any hypothesis becomes principle only after discussed from various angles (Ch. Vi. 8/37).
- Haritaki has tridoshara property and anuloma all vitiated dosha, which is helpful in further treatment.

- Nasya karma is also good for urdhva jatrugata rogas because drug administered through nose as nasya reaches to brain and eliminate the morbid doshas responsible for producing disease.

- The Phalatrikadi ghrita used in tarpana procedure is combination of ghrita and decoction of medicines, hence the drug has quality to transpassing into minute channels of body hence when applying on eyes it enters deeper layer in eyes and clean every minute part.

The clinical trial drug Phalatrikadi Ghrita has predominance of Madhura rasa, Guru guna, Sheeta veerya, and Madhura vipaka. Considering the doshakarma, the trial drug is Vatashamaka, Pittashamaka and Kaphashamaka by virtue of its Rasa, Guna, Veerya and Vipaka. Thus, the overall effect of the compound drug is Tridoshashamaka and hence it disintegrates the pathology of the disease Timira, which is Vata pradhana Tridoshaja in its manifestation.

- The Phalatrikadi Ghrita used as Tarpana may have its action at the 
level of cornea, lens and ciliary muscle. The fat soluble contents of the drugs get absorbed through transcorneal route may have action on the refractive media of the eye and eye as a whole. So it is supposed that after getting absorbed from ocular surface fatty acids enters in Aqueous
Chamber and nourishes intraocular contents, especially Uveal tract (Iris, Ciliary body) and lens. The absorbed contents of Goghrita help in restoring the muscular power of ciliary body and lens flexibility, which is essential for accommodation.

PHARMACODYNAMIC ACTION OF PHALATRIKADI GHRITA:-

\begin{tabular}{|c|c|c|c|c|c|c|}
\hline Dravya & Rasa & Guna & Virya & Vipaka & Doshaghnata & Karma \\
\hline $\begin{array}{l}\text { Haritaki } \\
\text { (Terminalia } \\
\text { chebula) }\end{array}$ & $\begin{array}{l}\text { Lavana } \\
\text { varjita } 5 \\
\text { rasa }\end{array}$ & $\begin{array}{l}\text { Laghu, } \\
\text { Ruksha }\end{array}$ & Ushna & Madhura & Tridoshashamaka & $\begin{array}{l}\text { Medhya, } \\
\text { Chakshushya } \\
\text { Rasayana, } \\
\text { Shoolahara }\end{array}$ \\
\hline $\begin{array}{l}\text { Vibhitaki } \\
\text { (Terminalia } \\
\text { bellirica) }\end{array}$ & Kashaya & $\begin{array}{l}\text { Laghu, } \\
\text { Ruksha }\end{array}$ & Ushna & Madhura & Tridoshashamaka & $\begin{array}{l}\text { Netrya, } \\
\text { Krimighna }\end{array}$ \\
\hline $\begin{array}{l}\text { Amalaki } \\
\text { (Emblica } \\
\text { officinalis) }\end{array}$ & $\begin{array}{l}\text { Lavana } \\
\text { varjita } 5 \\
\text { rasa }\end{array}$ & $\begin{array}{l}\text { Guru, } \\
\text { Ruksha, } \\
\text { Sheeta }\end{array}$ & Sheeta & Madhura & Tridoshashamaka & Rasayana \\
\hline $\begin{array}{l}\text { Shatavari } \\
\text { (Asparagus } \\
\text { racemosus) }\end{array}$ & $\begin{array}{l}\text { Madhura } \\
\text { Tikta }\end{array}$ & $\begin{array}{l}\text { Guru, } \\
\text { Snigdha }\end{array}$ & Sheeta & Madhura & Vatapittashamaka & $\begin{array}{l}\text { Medhya, } \\
\text { Rasayana, } \\
\text { Chakshushya }\end{array}$ \\
\hline $\begin{array}{l}\text { Yashtimadhu } \\
\text { (Glycrrhiza } \\
\text { glabra) }\end{array}$ & Madhura & $\begin{array}{l}\text { Guru, } \\
\text { Snigdha }\end{array}$ & Sheeta & Madhura & Vatapittashamaka & $\begin{array}{l}\text { Dahashamaka, } \\
\text { Medhya, } \\
\text { Chakshushya, } \\
\text { Rasayana }\end{array}$ \\
\hline $\begin{array}{l}\text { Goghrita } \\
\text { (Butyrum } \\
\text { deparatu) }\end{array}$ & Madhura & $\begin{array}{l}\text { Guru, } \\
\text { Snigdha, } \\
\text { Mridu }\end{array}$ & Sheeta & Madhura & Vatapittashamaka & $\begin{array}{l}\text { Medhya, } \\
\text { Rasayana, } \\
\text { Chakshushya, } \\
\text { Balya }\end{array}$ \\
\hline
\end{tabular}




\section{CONCLUSION-}

- Prathama and dwitiya patalgata Timira are drishtigata roga can be correlated with in modern science with Myopia

- Phalatrikadi ghrita tarpana has significant effect in pacify the symptoms of Myopia and marked reduction in clinical symptoms was well appreciated within tarpana therapy.

- No adverse effect of drug were observed during the course of study after administration.

- The Phalatrikadi ghrita tarpana is proved to be cost effective, safe and better drug as tarpana for Myopia. Rasayana property drugs helps in further degeneration of th tissue.

\section{REFERENCES-}

1. Sushruta samhita, Uttara tantra, Kaviraj Ambikadutta Shastri, Chaukhamba Sanskrit Sansthan, Varanasi, Edition-Reprint 2011

2. Ashtang hridyam, Uttara sthan, Kaviraj Atridev Gupta,
Chaukhamba Prakashan, Varanasi, Reprint 2012

3. Charaka Samhita, Bramhanand Tripathi, Surbharti Prakashan, Reprint 2011

4. Bhavaprakasha Nighantu, Shri. Bhavamishra Commentary by Dr. K.C. Chunekar, Edited by Dr. G.S. Pandey, Chaukambha Sanskrit Sansthan, Varanasi,4th Edition 1969

5. Chakradatta with padarth bodhini commentary by vaidya Ravidutta Shastri

6. Dravya Guna Vigyan, Acharya Priyavat Sharma, Chaukhambha Bharati Academy, Varanasi. Edition-2001.

7. Comprehensive Ophthalmology, A.K. Khurana,New age international limited, 4th edition 2007.

8. Parsons' Diseases of the Eye, Ramanjit Sihota, Elsevier publication, 22nd edition, 2011

Cite article

A clinical study of Phalatrikadi Ghrita Tarpana In The Management of Myopia Rajendra Singh Patel, Yogesh Kumar Sisodiya, Tushar Firke Ayurlog: National Journal of Research in Ayurved Science- 2018; (6)(5) 1-8 